\title{
Separation and Characterization of Immunoglobulin Classes of Anti-Salmon Sperm Deoxyribonucleic Acid Antibodies in Rabbits
}

\author{
Tsutomu Matsumoto* and Eiji Okunara \\ Department of Biochemistry, Akita University School of \\ Medicine, Akita
}

\begin{abstract}
Matsumoto, T. and Okuhara, E. Separation and Characterization of Immunoglobulin Classes of Anti-Salmon Sperm Deoxyribonucleic Acid Antibodies in Rabbits. Tohoku J. exp. Med., 1974, 113 (3), 245-255—_ Immunoglobulin classes of antibodies to salmon sperm deoxyribonucleic acid (ssDNA) induced by heat-denatured ssDNA-methylated bovine serum albumin (MBSA) conjugates were separated and characterized, and an anamnestic response to the conjugates was reinvestigated. (1) Antibodies to ssDNA were present in both IgM and IgG. On the contrary, antibodies to polyA-polyU and polyI-polyC occurred exclusively in IgG. (2) $\operatorname{IgM}$ and $\operatorname{IgG}$ were purified by appropriate combinations of gel filtration, ammonium sulfate fractionation, sucrose density centrifugation and DEAE-cellulose chromatography, and their antibody activities were reconfirmed. (3) A single dose of a ssDNA-MBSA complex did not induce primary antibody synthesis in rabbits, but booster injections elicited the antibody. One year after stopping the booster injection, the immunological memory for antibody production almost disappeared, and the antibody producing capacity fell remarkably. anti-DNA antibody; immunoglobulin
\end{abstract}

This work was initiated in the hope of finding some differences between cancer cells and normal cells by introducing immunological methods to the chemistry of nucleic acids. Earlier findings had made it clear that chemically pure DNA is not immunogenic whereas it can function as an immunogen if it is linked to a carrier. "The coupling method" (Butler et al. 1962; Tanenbaum and Beiser 1963; Plescia et al. 1964, 1965; Erlanger and Beiser 1964; Sela et al. 1964; Halloran and Parker 1966) opened a way to the production of antibodies to nucleic acids as haptens. It is now recognized that antisera thus produced might be useful as a new analytical tool in the study of the structure and function of nucleic acids. The previous report (Okuhara and Matsumoto 1969) has shown that both precipitating and complement-fixing antibodies were demonstrable in the antisera to thermally denatured ssDNA and thermally denatured Yoshida Sarcoma DNA. Although the antisera cross-reacted with DNA preparations from other various sources, there were differences in the reactivities. However, little information is available concerning the antibody to DNA induced experimentally in the sera of rabbits. In 1966, Stollar and Sandberg stated that at all times, all detectable

Received for publication, May 27, 1974.

* Present address: Akita Agricultural College, Akita. 
serum antibodies were macroglobulins in their immune system. This was reconfirmed by Forsén et al. (1970). Considering their interesting findings, the authors studied the immunoglobulin classes of antibodies induced by ssDNA-MBSA complexes and compared them with antibodies to polyA.polyU and polyI polyC.

\section{Materials and Methods}

Preparation of antisera to DNAs: Highly polymerized salmon sperm DNA, purchased from Worthington Biochemical Corp., was used for preparation of the immunizing antigen. The DNA prepared by the usual method (Okuhara 1970) in our laboratory was also used for the serological tests. Both DNA were found to be a real antigen by the deoxyribonuclease I (EC 3.1.4.5) treatment and inhibition test (Okuhara and Matsumoto 1969).

Homopolymers of riboadenylate, ribouridylate, riboinosinate and ribocytidylate (polyA, polyU, polyI and polyC) were purchased from Miles Laboratories. The doublehelical polyribonucleotides, polyA.polyU and polyI-polyC, were prepared according to the method cited by Schwarts and Stollar (1969). The antiserum was produced by the repeated immunization of rabbits with heat-denatured ssDNA-MBSA complex according to the method developed by Plescia et al. (1964). The complex $(0.5 \mathrm{mg}$ dose of the DNA) emulsified with an equal volume of complete Freund's adjuvant was injected at intramuscular sites in rabbits at one or two week intervals, and blood was drawn one or two weeks after the fifth injection. Complements present in the sera were inactivated by incubation at $56^{\circ} \mathrm{C}$ for $30 \mathrm{~min}$ and then cold hemagglutinins were removed by absorption on erythrocytes at low temperature. The sera thus prepared were lyophilized and kept at $-20^{\circ} \mathrm{C}$. The antisera to polyA.polyU and polyI.polyC were produced by the same method as for the anti-ssDNA antiserum $(0.25 \mathrm{mg}$ of respective co-polymers per rabbit, 5 injections).

To examine the purity of a purified IgG, goat anti-whole rabbit serum was prepared. A single goat was immunized with intramuscular injections of $1 \mathrm{ml}$ of rabbit serum with complete Freund's adjuvant at one week intervals. The blood was drawn one week after the third injection.

Complement fixation: A modification (cf. Ref. 24) of the quantitative micromethod of Kolmer was used. The procedure for $\mathrm{C}^{\prime}$-fixation was as follows: The mixture of 0.1 $\mathrm{ml}$ of appropriately diluted antiserum, $0.1 \mathrm{ml}$ of antigen $(10 \mu \mathrm{g}$ of DNA/ml of $0.15 \mathrm{M} \mathrm{NaCl})$ and $0.2 \mathrm{ml}$ of $\mathrm{C}^{\prime}\left(2\right.$ units) were allowed to stand overnight at $4^{\circ} \mathrm{C}$. Then $0.2 \mathrm{ml}$ of a (3 units of hemolysin)-(red cells) mixture was added and the whole mixture was incubated at $37^{\circ} \mathrm{C}$ for $30 \mathrm{~min}$. After centrifugation, hemoglobin in the supernatant was measured spectrophotometrically at $541 \mathrm{~nm}$. Serum titres were determined as the reciprocal of the serum dilution required for 50 per cent maximal $\mathrm{C}^{\prime}$-fixation.

Double diffusion tests and immunoelectrophoresis: These were carried out on glass microscope slides: double diffusion tests, in 0.9 per cent agar in $0.01 \mathrm{M}$ phosphate buffer pH 7.4, containing $0.15 \mathrm{M} \mathrm{NaCl}$; immunoelectrophoresis, in 1 per cent agar in $0.06 \mathrm{M}$ barbital

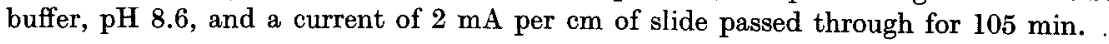

Cellulose acetate electrophoresis: 'Separax,' cellulose acetate membrane filter strips made by Fuji Film Co., Japan, was used. The operation was conducted according to the instructions described by Ogawa (1969).

Sucrose density gradient centrifugation: A linear sucrose density gradient from 5 to

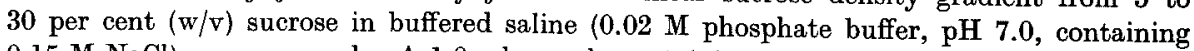
$0.15 \mathrm{M} \mathrm{NaCl}$ ) was prepared. A $1.0-\mathrm{ml}$ sample containing $4 \mathrm{mg}$ of IgG or IgM was layered on the surface. Tubes were centrifuged in a Hitachi Model 65-P centrifuge, with a RPS $25-3 \mathrm{~A}$ rotor, for $26 \mathrm{hr}$ at $22,500 \mathrm{rev} / \mathrm{min}$. $0.25-\mathrm{ml}$ fractions were collected by the use of ISCO density gradient fractionator. 
Results

\section{Anamnestic response patterns}

Three rabbits (Nos. 9, 10 and 11) were injected denatured DNA, at a dose of $0.5 \mathrm{mg}$, at two week intervals. Fig. 1 shows the responses of rabbits Nos. 9,10 and 11. There was no detectable antibody production in response to the first injection. Antibodies were detectable two weeks after the second injection. The titres for 50 per cent maximal C'-fixation were highest two weeks after the third injection in rabbits Nos. 9 and 10, and in rabbit No. 11, two weeks after the fourth injection. The titres were not increased by further injections. In rabbits Nos. 9 and 10, the maximal titres were maintained for about four weeks. In rabbit No. 11, the titres reached the peak value at eight weeks after the first injection and then declined slowly. In rabbit No. 10, one year after the fifth injection, the antibody activity was not detectable. Then, rabbit No. 10 was given seven additional injections at one week intervals. The titre reached a peak value six weeks after resuming immunization, but the value was very low, indicating that the capacity of antibody production in the second series of immunization was much lower than in the first series. The immunological memory for production of antibody to DNA seems to have been lost after one year.

The differences in antibody-producing capacity observed between rabbits Nos. 9-11 may depend on individuality of each rabbit. To ascertain further the individual variations, four rabbits Nos. 1-4 were immunized under the same conditions as described above. Titres obtained for 50 per cent maximal C'fixation with sera of rabbits Nos. 1,2, 3 and 4 were 1024, 2048, 128 and 256, respectively.

Antibody activity in classes of immunoglobulins from anti-ssDNA antiserum

The serum was fractionated by Sephadex G-200 column chromatography (Killander and Hogman 1969) into IgG and $\operatorname{IgM}$, and the antibody activity of each class of immunoglobulins was examined by C'-fixation. As shown in Fig. 2 , antibody activity in the antiserum of rabbit No. 9 was demonstrable only in IgM fraction. This was independent of the frequency of injection. In rabbit No. 10, after two injections the antibody activity was found only in the IgM fraction, and after five injections, the activity in IgG was greater than that in IgM.

The same experiments as in Fig. 2 were performed with sera of hyperimmunized rabbits Nos. 1, 2 and 4 . In rabbit No. 1 (Fig. $3 \mathrm{~A}$ ), the antibody activity in IgG was more potent than that in IgM. In rabbit No. 2 (Fig. 3 B), the activity pattern reversed. In rabbit No. 4 (Fig. $3 \mathrm{C}$ ), the antibody activities found in IgM and IgG fractions were almost the same. It is important that antibody activity persisted definitely in IgM fraction in every case even after hyperimmunization.

Next, antibodies to polyA polyU and polyI - polyC were prepared and the antibody activity of the immunoglobulin classes was investigated in comparison with anti-DNA antibody. All procedures of immunization, fractionation of immuno- 


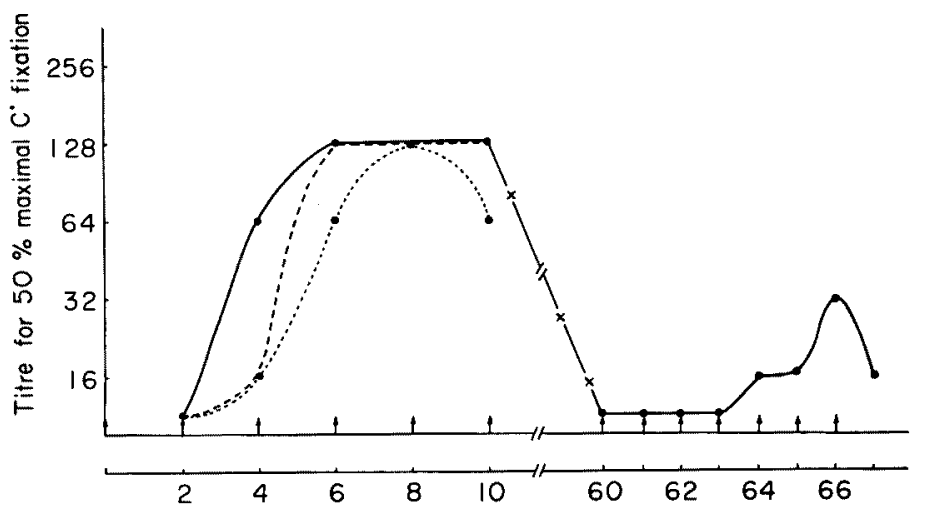

Weeks ofter first injection

Fig. 1. Anamnestic response patterns of three rabbits (No. $9(\bullet-. \bullet)$, No. $10(\bullet-\bullet)$, and No. $11(\cdots \cdot \bullet)$ immunized with heat denatured salmon sperm DNA-MBSA complex. At points indicated by arrows, the complex containing $0.5 \mathrm{mg}$ of the DNA was injected intramuscularly to each rabbit.

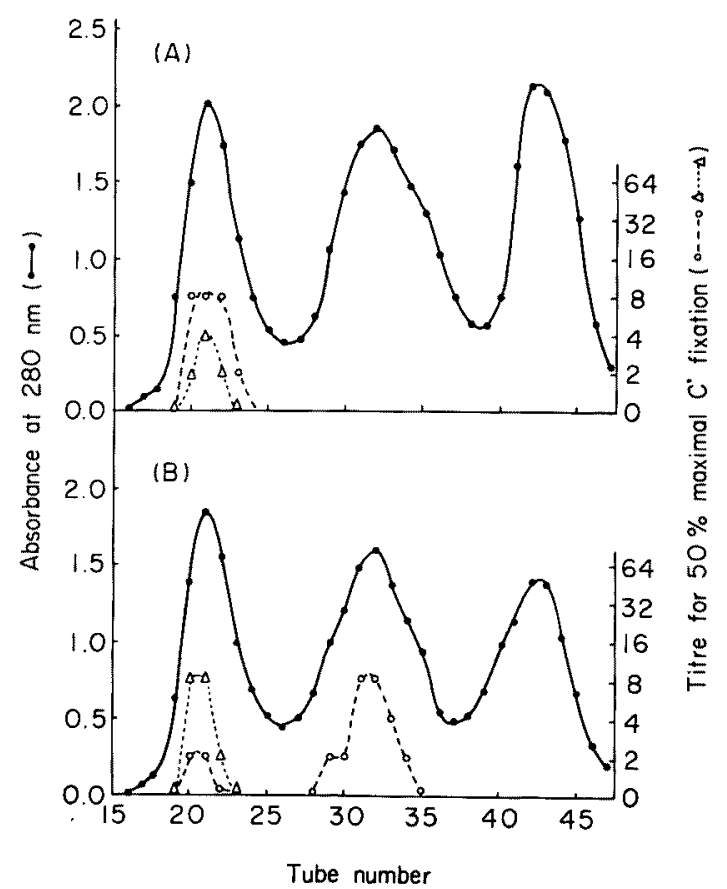

Fig. 2. Sephadex G-200 Column Chromatography of Anti-ssDNA Antisera. (A), Antibody activity of the serum of rabbit No. 9 drawn two weeks after the third injection $(\Delta-\ldots)$, and two weeks after the fifth injection ( $(0--0)$. (B), Antibody activity of the serum of rabbit No. 10 drawn two weeks after the second injection $(\Delta-\ldots, \Delta)$ and two weeks after the fifth injection $(0-\cdots)$. A column $(2.6 \times 30 \mathrm{~cm})$ applied with $2 \mathrm{ml}$ of the antiserum was eluted with buffered saline $(0.05 \mathrm{M}$ phosphate buffer, $\mathrm{pH} 7.3$, containing $2.2 \% \mathrm{NaCl}$ and $0.02 \%$ sodium azide) at $4^{\circ} \mathrm{C}$. 3-ml fractions were collected and the flow rate was approximately $5 \mathrm{ml} / \mathrm{hr}$. 


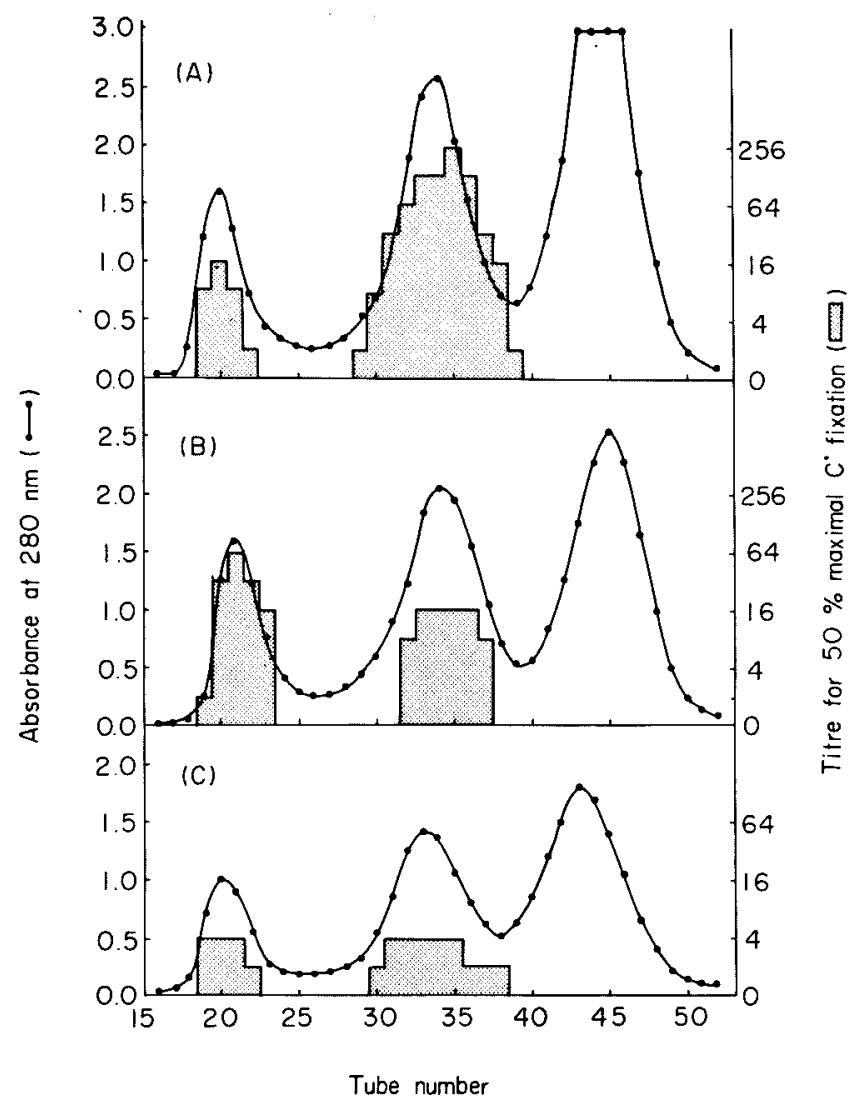

Fig. 3. Antibody activities of IgM and IgG fractionated by Sephadex G-200 column ehromatography of anti-ssDNA antisera of rabbits No. 1, No. 2 and No. 4. Each rabbit was immunized with the complex containing $0.5 \mathrm{mg}$ of the DNA at one week intervals and bled one week after the fifth injection.

(A), rabbit No. 1; (B), rabbit No. 2; (C), rabbit No. 4.

globulin classes, and determination of antibody activity were conducted in the same manner as for the cases with DNA. As shown in Fig. 4, in every case, the antibody activity of the $\operatorname{IgM}$ fraction was very weak and a greater activity was found in IgG fraction. These results indicate that the immunoglobulin class of anti-ssDNA antibody includes both IgG and IgM with the exception of rabbit No. 9 which produced only IgM, and the antibody activity of IgM was rather potent in comparison with antibodies to polyA.polyU and polyI.polyC.

\section{Identification of $\operatorname{Ig} M$ and $\operatorname{Ig} G$}

a) 2-Mercaptoethanol treatment of antisera. Anti-DNA antiserum of rabbit No. 2 was treated with 2-mercaptoethanol as usual, and fractionated by Sephadex G-200 column chromatography into IgG and IgM. The antibody activity of each fraction was examined by C'-fixation test. As shown in Fig. 5, after treatment 


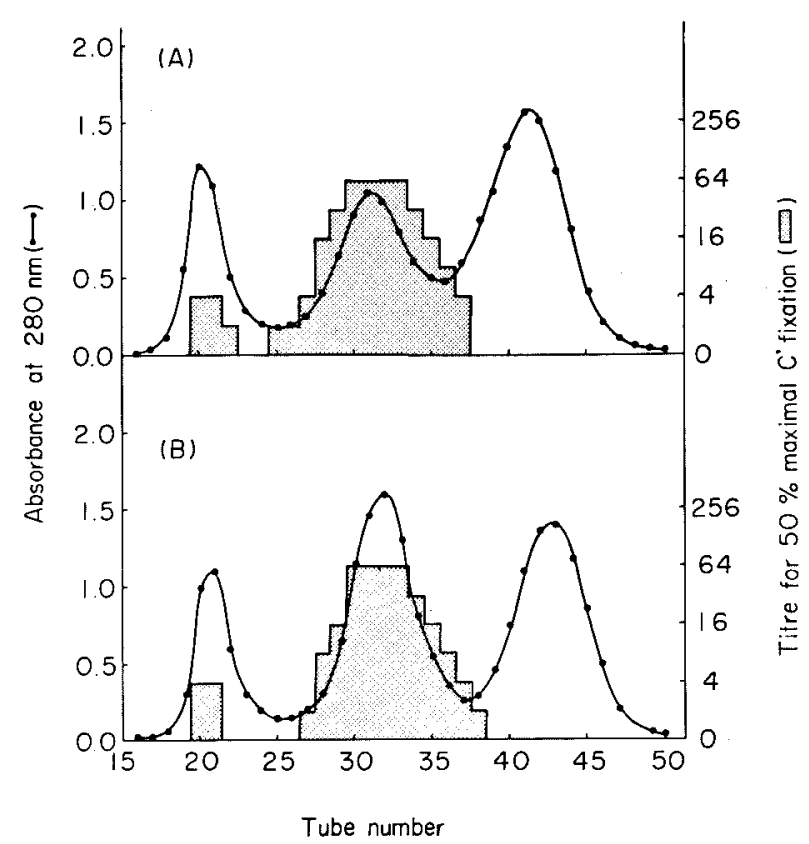

Fig. 4. Antibody Activities of IgM and IgG fractionated by Sephadex G-200 Column chromatography of anti-PolyA.PolyU and anti-PolyI-PolyC antisera. Rabbits were given five injections of the complex containing $0.25 \mathrm{mg}$ of polyA-polyU or polyI. polyC, and bled one week after the last injection.

(A), anti-polyA-polyU antiserum of rabbit No. 12 ; (B), anti-plyI.polyC antiserum of rabbit No. 15 .

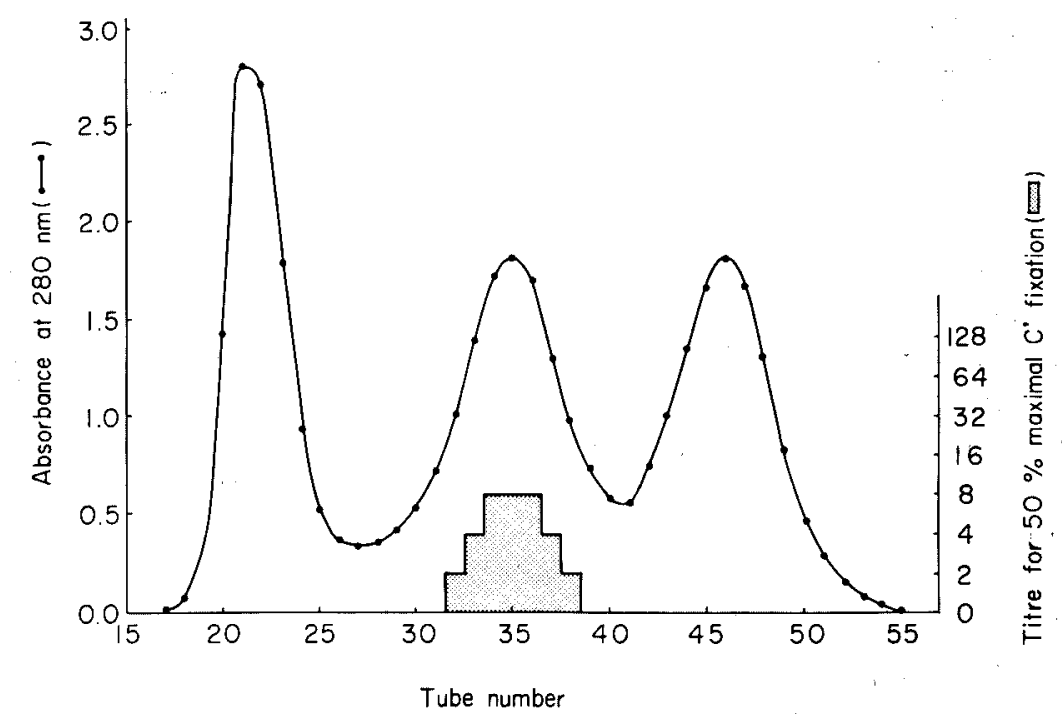

Fig. 5. Antibody activities of IgM and IgG fractionated by Sephadex G-200 column chromatography of anti-ssDNA antiserum of rabbit No. 2 treated with $0.1 \mathrm{M} 2$ mercaptoethanol. 


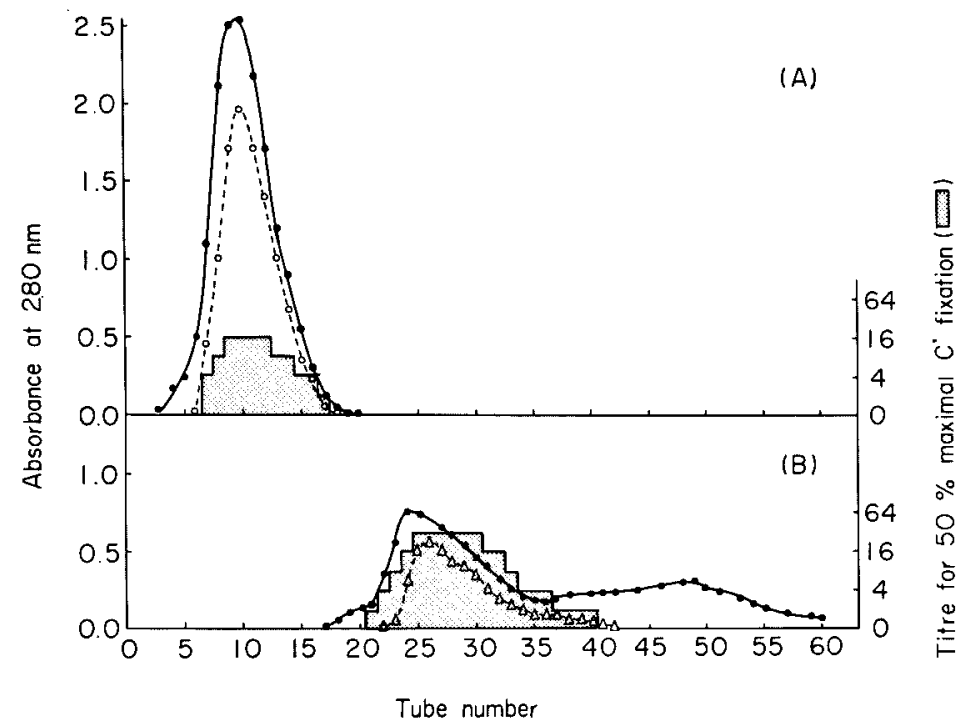

Fig. 6. Sucrose density gradient centrifugation of $\operatorname{IgM}(\mathrm{B}, \bullet \bullet \bullet)$ and $\operatorname{IgG}(\mathrm{A}, \bullet \bullet \bullet)$ from antiserum of rabbit No. 2. $\gamma$-Globulin (o- - - ) isolated from the rabbit sera was used as a $7 \mathrm{~S}$ marker and thyroglobulin $(\Delta---\Delta)$ as a $19 \mathrm{~S}$ marker. Each marker was centrifuged simultaneously in a separate tube. $0.25-\mathrm{ml}$ fractions were collected from the top of the tubes by using ISCO density-gradient fractionator.

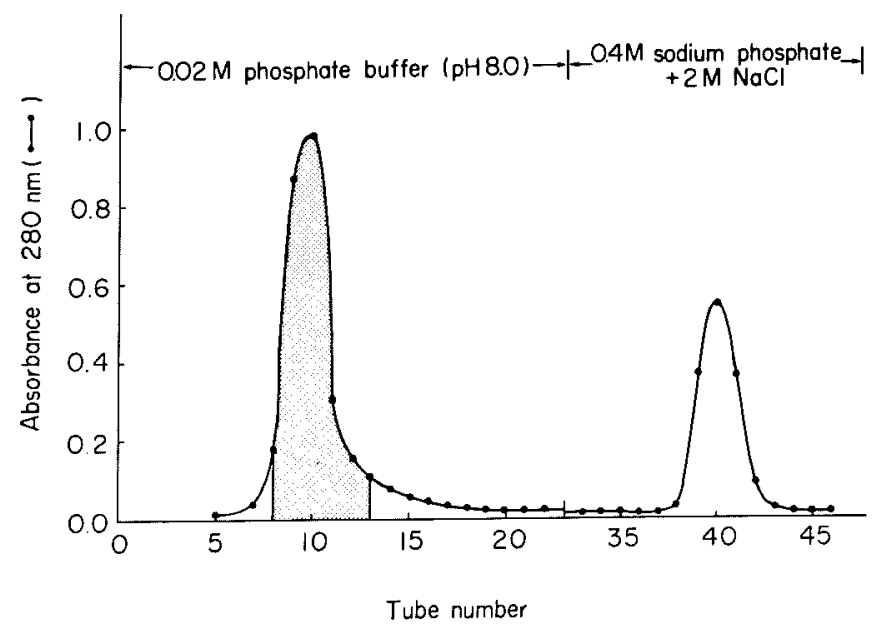

Fig. 7. DEAE-Cellulose column chromatography of IgG fraction from anti-ssDNA antiserum of rabbit No. 1. A column $(2.6 \times 17 \mathrm{~cm})$ was applied with $5 \mathrm{ml}$ of IgG fraction which had been obtained from $6 \mathrm{ml}$ of the antiserum by Sephadex G-200 column chromatography and then it was eluted by stepwise elution with $0.02 \mathrm{M}$ phosphate buffer, $\mathrm{pH} 8.0$, and $0.40 \mathrm{M}$ sodium phosphate, $\mathrm{pH} 4.4$, containing $2 \mathrm{M} \mathrm{NaCl}$ at $4^{\circ} \mathrm{C}$. Each fraction was $8 \mathrm{ml}$ and the flow rate was approximately $90 \mathrm{ml} / \mathrm{hr}$. The shaded area in the elution diagram was collected as the purified IgG. 

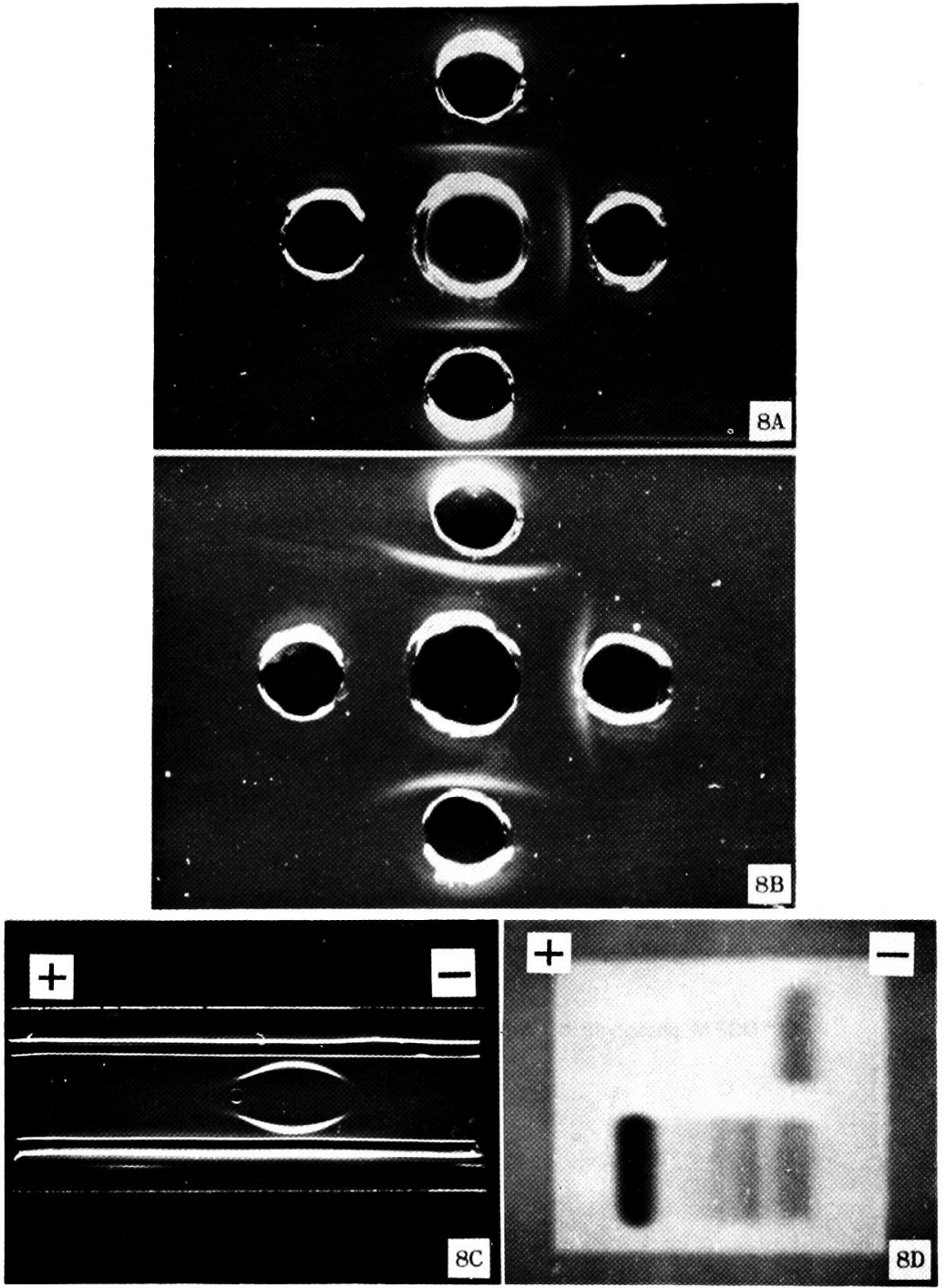

Fig. 8. A and B. Double diffusion tests of $\operatorname{IgM}$ and $\operatorname{IgG}$ purified from the antiserum prepared with ssDNA. Centre wells of $A$ and $B$ contained the purified $\operatorname{IgM}$ (19.255 $\mathrm{A}_{280}$ units) and IgG (17.58 $\mathrm{A}_{280}$ units), respectively. The peripheral wells contained ssDNA at various concentrations: $20 \mu \mathrm{g}, 12$ o'clock; $10 \mu \mathrm{g}, 3$ o'clock; $5 \mu \mathrm{g}, 6$ o'clock; saline, 9 o'clock.

Fig. 8 C. Immunoelectrophoretic patterns of IgG from the antiserum. Troughs, goat anti-whole rabbit antiserum; centre well, purified IgG. Details of the procedures are described under "Methods."

Fig. 8 D. Cellulose acetate electrophoretic patterns of IgG from anti-ssDNA antiserum. Upper pattern, IgG; lower pattern, whole rabbit serum. $0.8 \mathrm{~mA} / \mathrm{cm}$ of width of the strip was passed through in $0.06 \mathrm{M}$ barbital buffer, $\mathrm{pH} 8.6$, for $35 \mathrm{~min}$, and then stained with $0.8 \%$ Ponceau $3 \mathrm{R}$ in $6 \%$ trichloroacetic acid. 
of the serum with mercaptoethanol, the antibody activity of IgM disappeared, while that of IgG remained unchanged. These ascertains that two kinds of antibodies, IgM and IgG, were produced on immunization with ssDNA-MBSA complex.

b) Sucrose density gradient centrifugation. IgM and IgG obtained by Sephadex G-200 column chromatography of the antiserum of rabbit No. 2 were further purified using sucrose density gradient centrifugation and the activities in respective fractions were determined by C'-fixation as in the text. Fig. $6 \mathrm{~B}$ shows that the rate of sedimentation of the fraction having antibody activity in the $\operatorname{IgM}$ peak was quite similar to that of the $19 \mathrm{~S}$ thyroglobulin.* Similarly, the antibody activity of the IgG peak was recovered in the fraction which co-sedimented with $7 \mathrm{~S} \gamma$-globulin $\dagger$ as shown in Fig. $6 \mathrm{~A}$. The purified IgM for ssDNA was also examined by a double diffusion test, and precipitating antibody was demonstrated by the formation of a single precipitating line (Fig. $8 \mathrm{~A}$ ).

c) DEAE-cellulose column chromatography (Sober and Peterson 1958). The IgG fraction separated by Sephadex G-200 column chromatography was further purified using DEAE-cellulose column chromatography (Fig. 7). The purity was checked by cellulose acetate electrophoresis and immunoelectrophoresis, and it was found to be pure as seen in Fig. $8 \mathrm{C}$ and Fig. $8 \mathrm{D}$. The antibody activity of purified IgG was checked by C'-fixation. As shown in Table 1, more than $2 \mu \mathrm{g}$ of purified IgG reacted with $1 \mu \mathrm{g}$ of denatured ssDNA. In addition, a single precipitating line was formed in the double diffusion test of purified IgG with denatured ssDNA (Fig. 8 B).

TABLE 1. C'-fixation of purified IgG with thermally denatured ssDNA

\begin{tabular}{cc}
\hline $\operatorname{IgG}(\mu \mathrm{g} / 0.1 \mathrm{ml})$ & C'-Fixation $(\%)$ \\
\hline 0.5 & 0 \\
1 & 0 \\
2 & 25 \\
4 & 50 \\
8 & 100 \\
16 & 100 \\
32 & 100
\end{tabular}

$1 \mu \mathrm{g}$ of thermally denatured ssDNA was employed.

\section{Discussion}

In our immune system using ssDNA as antigen, the immunogenicity and immunoglobulin class of the antibody were investigated and compared with the cases with polyA - polyU and polyI - polyC. The detectable antibody was not induced in rabbits by a single dose of denatured ssDNA-MBSA complex, but the antibody was elicited by the booster injection. The same result was obtained when polyA. polyU and polyI-polyC were used as immunogen. In accordance with the results

* Commercially obtained (from Miles Laboratories).

$\dagger$ Isolated from rabbit sera, and its purity was identified. 
by Sandberg and Stollar (1966), it is assumed that a single injection of nucleic acids does not induce the primary antibody. The immunogenicity of ssDNA was not potent, and mouse fetus DNA did not appear to have appreciable immunogenicity (unpublished observation). On the other hand, polyA.polyU and polyI. polyC showed quite potent immunogenicity (Matsumoto and Okuhara 1972). Therefore, it is believed that immunogenicity depends on certain kinds of nucleic acids which contain different determinant groups. It is unknown what determines the appearance of different classes of immunoglobulins, but the literatures (Ordal and Grumet 1972; Silver et al. 1972; Gruenewald and Stollar 1973; Stollar et al. 1973) suggest that antigenic and genetic factors are involved. In our experiments, one of five rabbits employed had the antibody activity only in IgM even after hyperimmunization. In two of the remaining rabbits, both $\operatorname{IgM}$ and IgG had almost the same antibody activities and IgM showed rather a more potent activity than IgG. In the remaining two rabbits, the change in the pattern of antibody production, that is, from IgM to IgG, was recognized after hyperimmunization. On the other hand, antibodies to polyA.polyU and polyI.polyC produced in six rabbits were found to have potent activities in IgG of immunoglobulins. From these experiments, it is clear that the pattern of immunoglobulin classes is markedly affected by kinds of nucleic acids in addition to some genetic factors. Very recently, during the study of the adjuvant effect of polyA-polyU in producing antibodies to DNA, we found an unexpected case in which "IgM type" changed to "IgG type" (Igarashi et al. 1973). It is interesting that polyA-polyU used as adjuvant played a role in determining the classes of immunoglobulins produced. Most of the antibodies to DNA in sera from patients with systemic lupus erythematodes are IgG (Stollar and Sandberg 1966; Pincus and Kaplan 1970). Probably the kinds of DNA acting as immunogens as well as the genetic responses are different between rabbits and human patients. These differences may reflect the differences in the control mechanisms which determine the different classes of immunoglobulins. In rabbit No. 10, both $7 \mathrm{~S}$ and $19 \mathrm{~S}$ antibodies entirely disappeared one year after the last injection of antigen. Subsequently, rabbit No. 10 was further injected six more doses, which resulted in appearance of a C'-fixation titre of $1: 32$ in the serum. This titre was very low in comparison with that of the serum obtained by the previous series of immunizations. These observations may provide an advanced basis for the study of the mechanisms which control the immunological memory and the determination of different classes of immunoglobulins.

\section{References}

1) Butler, V.P., Jr., Beiser, S.M., Erlanger, B.F., Tanenbaum, S.W., Cohen, S. \& Bendich, A. (1962) Purine-specific antibodies which react with DNA. Proc. nat. Acad. Sci. (Wash.), 48, 1597-1602.

2) Erlanger, B.F. \& Beiser, S.M. (1964) Antibodies specific for ribonucleosides and ribonucleotides and their reaction with DNA. Proc. nat. Acad. Sci. (Wash.), 52, 6874. 
3) Forsen, N.R., Alspaugh, M. \& Barnett, E.V. (1970) Precipitating antibodies to DNA induced by heat-denatured DNA-albumin conjugates in the rabbit. Immuno$\log y, 19,669-676$.

4) Gruenewald, R. \& Stollar, B.D. (1973) The role of antigenic determinants in the control of IgM and IgG antibody responses to denatured DNA. J. Immunol., 111, 106-113.

5) Halloran, M.J. \& Parker, C.W. (1966) The preparation of nucleotide-protein conjugates: Carbodiimides as coupling agents. J. Immunol., 96, 373-378.

6) Igarashi, J., Matsumoto, T. \& Okuhara, E. (1973) The effect of PolyA.PolyU on the production of antibodies to DNA. Seikagaku (Jap.), 45, 537.

7) Killander, J. \& Hogman, C.F. (1969) Fractionation of serum proteins by Gel filtration on sephadex G-200. In: Basic Exercises in Immunochemistry, edited by A. Nowotny, Springer-Verlag, Heidelberg, p. 5.

8) Matsumoto, T. \& Okuhara, E. (1972) The production of antibodies to synthetic double-helical polyribonucleotides. Seikagaku (Jap.), 44, 408.

9) Ogawa, J. (1969) Cellulose Acetate Electrophoresis, in Methods of Electrophoresis, Bunkodo, Tokyo, p. 111.

10) Okuhara, E. (1970) Preparation of mammalian DNA by SDS-phenol treatment. Analyt. Biochem., 37, 175-178.

11) Okuhara, E. \& Matsumoto, T. (1969) Immunochemical studies of nucleic acids. Jap. Proc. of the Symposium on Immunochemistry, Osaka, Japan, 3, 1-4.

12) Ordal, J.C. \& Grumet, F.C. (1972) Genetic control of the immune response. J. exp. Med., 136, 1195-1206.

13) Pincus, T. \& Kaplan, A.P. (1970) True antibodies to DNA in systemic lupus erythematosus: Activity of $\mathrm{Fab}$ and $\mathrm{F}(\mathrm{ab})_{2}$ fragments. Nature, 227, 394.

14) Plescia, O.J., Braun, W. \& Palczuk, N.C. (1964) Production of antibodies to denatured DNA. Proc. nat. Acad. Sci. (Wash.), 52, 279-285.

15) Plescia, O.J., Palczuk, N.C., Cora-Figueroa, E., Mukherjee, A. \& Braun, W. (1965) Production of antibodies to soluble RNA. Proc. nat. Acad. Sci. (Wash.), 54, 12811285.

16) Sandberg, A.L. \& Stollar, B.D. (1966) A $19 \mathrm{~S}$ anamnestic response to DNA-MBSA complexes. Immunology, 11, 547-556.

17) Schwartz, E.F. \& Stollar, B.D. (1969) Antibodies to PolyA.PolyU copolymers as reagents for double strand RNA and DNA-RNA hybrid complexes. Biochem. Biophys. Res. Commun., 35, 115-120.

18) Sela, M., Ungar-Waron, H. \& Shechter, Y. (1964) Uridine-specific antibodies obtained with synthetic antigens. Proc. nat. Acad. Sci. (Wash.), 52, 285-292.

19) Silver, D.M., McKenzie, I.F.C. \& Winn, H.J. (1972) Variation in the responses of C57BL/10J and A/J mice to sheep red blood cells. J. exp. Med., 136, 1063-1071.

20) Sober, H.A. \& Peterson, E.A. (1958) Protein chromatography on ion exchange cellulose. Fed. Proc., 17, 1116.

21) Stollar, B.D., Fuchs, S. \& Mozes, E. (1973) Immune response of mice to nucleic acids: strain-dependent differences in magnitude and class of antibody production. J. Immunol., 111, 121-129.

22) Stollar, B.D. \& Sandberg, A.L. (1966) Comparisons of antibodies reacting with DNA. I. Systemic lupus erythematosus sera and rabbit antibodies induced by DNAMBSA complexes. J. Immunol., 96, 755-763.

23) Tanenbaum, S.W. \& Beiser, S.M. (1963) Pyrimidine-specific antibodies which react with DNA. Proc. nat. Acad. Sci. (Wash.), 49, 662-668.

24) Virus Zikken-Gaku, edited by Natl. Inst. of Health, Maruzen, Tokyo, 1964, p. 196. 